\title{
Short Communication: Isolation and identification of actinomycetes potential as the antagonist of Dickeya zeae pineapple soft rot in Lampung, Indonesia
}

\author{
TITIK NUR AENY ${ }^{1, \vartheta}$, JOKO PRASETYO ${ }^{1}$, RADIX SUHARJO ${ }^{1}$, SUSKANDINI R. DIRMAWATI ${ }^{1}$, EFRI $^{1}$, \\ AININ NISWATI ${ }^{2, v \varphi}$ \\ ${ }^{1}$ Department of Plant Protection, Faculty of Agriculture, Universitas Lampung. Jl. Prof. Soemantri Brojonegoro No. 1 Bandar Lampung 35145 \\ Lampung, Indonesia. Tel./fax.: +62-721-787029, ”email: titik.nuraeny@ff.unila.ac.id \\ ${ }^{2}$ Department of Soil Science, Faculty of Agriculture, Universitas Lampung. Jl. Prof. Soemantri Brojonegoro No. 1 Bandar Lampung 35145, Lampung, \\ Indonesia. Tel./fax.: +62-721-781822, ^email: ainin.niswati@fp.unila.ac.id
}

Manuscript received: 10 August 2018. Revision accepted: 21 October 2018.

\begin{abstract}
Aeny TN, Prasetyo J, Suharjo R, Dirmawati SR, Efri, Niswati A. 2018. Isolation and Identification of actinomycetes potential as the antagonist of Dickeya zeae pineapple soft rot in Lampung, Indonesia. Biodiversitas 19: 2052-2058. This study was aimed to collect and identify actinomycetes from the rhizosphere of pineapple with the potency as a biocontrol agent of Dickeya zeae, the pathogen of pineapple soft rot. Soil samples were collected from four different pineapple plantations in Lampung Province, in December 2016. Samples were air-dried, serially diluted, and plated on modified ISP2 medium and several single characterized colonies were sub cultured and purified. The growing colonies were grouped into different colour series based on their aerial-mycelia and substratemycelia colors. Antagonistic activity of the actinomycetes isolates were evaluated against Dickeya zeae by agar diffusion method using the same medium agar lawn with the bacterial cultures. Selected antagonistic actinomycete isolates with the biggest clear zone formation were further characterized and identified molecularly based on 16S rDNA sequences. The results showed that as many as 34 actinomycete isolates collected from pineapple rhizosphere produced clear zones. Two isolates, namely GGF2-i5 and GGF4-i18, presented the biggest clear zone were proposed as the potential antagonist strains against D. zeae and identified as Streptomyces parvulus and Streptomyces hygroscopicus subsp. hygroscopicus, respectively. Both of the 16S rRNA gene sequences from those strains were deposited in the GenBank with the accession number MH170279 and MH170280, respectively.
\end{abstract}

Keywords: actinomycetes, Ananas comosus, antagonist, Dickeya zeae, Streptomyces

\section{INTRODUCTION}

An actinomycete is a group of gram-positive bacteria, aerobic, grow and have aerial hypha like fungi. These bacteria are growing abundantly and easily found in the soil, both in cultivated and uncultivated soils in various regions worldwide. Soil is known as the greatest source of actinomycetes, and a large number of antagonistic actinomycetes can be isolated from the soil rich in organic matter with a high $\mathrm{C} / \mathrm{N}$ ratio (Goodfellow and Williams 1983). A large number of antagonistic actinomycetes have been reported as the common producers of antibiotics, especially the genus Streptomyces (Al-Momani et al. 1999, Saadoun et al. 1999, Kumar et al. 2011). Streptomyces spp. has been known as species of actinomycetes which has characteristics as biocontrol agents of bacterial soil-borne pathogens because of their ability to produce secondary metabolites and biologically active substances including enzymes and antibiotics (Zamanian et al. 2005). Some Streptomyces spp. are commercially important microorganisms that have been widely developed for the production of enzymes, antibiotics, inhibitors of enzymes, and other bioactive secondary metabolites (Kaur et al. 2013, Ratnakomala et al. 2016). They were utilized in many different fields such as in the pharmaceutical industry
(Nithya and Ponmurugan 2012), animal feed or poultry (Dharmaraj and Dhevendaran 2010), food preservation (Ibrahim and El-Salam 2016) as well as in agricultural practices. They were also used widely as antibacterial, antibiotics, antifungi, pesticides, and anti-parasites (Oskay 2004, Goodfellow et al. 2007, Dhananjeyan et al. 2010, Kumar et al. 2011).

With respect to the management of plant pathogens, actinomycetes have been used as biocontrol agents of Erwinia amylovora, the bacterial pathogen of fireblight disease in apple and Agrobacterium tumefaciens, the crown gall pathogen (Oskay et al. 2004); Xanthomonas oryzae pv. oryzae, the causal agent of bacterial leaf blight on rice (Putra and Giyanto 2014), Pectobacterium carotovorum subsp. carotovorum (=Erwinia carotovora subsp. carotovora) and Burkholderia cepacia, the onion bacterial rot pathogens (Abdallah et al. 2013). Jeffrey (2008) reported that actinomycetes isolated from soil had an antagonistic reaction on fungal as well as bacterial pathogens, such as Fusarium palmivora, Bacillus subtilis, Pantoae dispersa and Ralstonia solanacearum. However, there has been very limited information concerning the use of actinomycetes as biocontrol agents of E. chrysanthemi (Dickeya spp.), the bacterial soft rot pathogen on pineapple (Prasetyo and Aeny 2014). This disease has been 
considered as a serious threat to many pineapples producing countries in the world that has recently been found in East Lampung - Indonesia. Therefore, to prevent the spread and development of the disease, it is necessary to study the management of the disease, including the use of pineapple rhizospheric actinomycetes as local biocontrol agents. The present study was aimed to isolate actinomycetes from pineapple rhizosphere, determine their inhibitory effect against Dickeya zeae, and identify the potential isolates.

\section{MATERIALS AND METHODS}

\section{Collection of soil samples and isolation of Actinomycetes}

The soil samples were taken during on December 2016 from the rhizosphere of four pineapples plantation sites located in Lampung, Indonesia namely Terbanggi Besar (Central Lampung), Way Jepara (East Lampung), Astomulyo-Punggur (Central Lampung), and MulyajayaTulang Bawang Tengah (West Tulang Bawang). Five pineapple plants were randomly selected from diagonal lines in each of the plantation sites. The soil samples were collected from each of the root systems of the selected pineapple plant, composited, kept in plastic bags, and stored in a cooler box during transportation to the Laboratory of Plant Disease at Faculty of Agriculture University of Lampung for actinomycetes isolation.

Prior to isolation, the soil was air-dried for a week (Jeffrey 2008). Soil samples were serially diluted by tenfold dilution using sterile distilled water. The dilutions were thoroughly mixed and aliquots of $0.1 \mathrm{ml}$ from each dilution were spread onto plastic Petri dish (diameter of 9 $\mathrm{cm})$ containing $10 \mathrm{~mL}$ of modified ISP2 medium $(4.0 \mathrm{~g}$ yeast extract, $10.0 \mathrm{~g}$ malt extract agar, $4.0 \mathrm{~g}$ dextrose, 20.0 $\mathrm{g}$ agar, and $1000.0 \mathrm{ml}$ distilled water, $\mathrm{pH} 7.3$ ). Plates were incubated at room temperature $\left(28{ }^{\circ} \mathrm{C}\right)$ for 14 days, and cultures of actinomycete isolates were selected based on their colony morphology with a typical chalky to leathery appearance and aseptate aerial hyphae (Patil et al. 2016). They were further tested for the Gram reaction to confirm the gram-positive bacteria and eliminate possible of gramnegative isolates by non-Gram staining (Powers 1995).

\section{Antagonistic test}

An antagonistic test was performed by agar diffusion method developed by Barakate et al. (2002). As much as 5 $\mathrm{ml}$ suspension of 24 hours pineapple isolate of Dickeya zeae $\left(\sim 10^{8} \mathrm{CFU} / \mathrm{mL}\right)$ was mixed thoroughly into $100 \mathrm{ml}$ nutrient agar (NA) media (HiMedia) and plated into plastic Petri dish (diameter of $9 \mathrm{~cm}$ ). The actinomycetes used in this step were taken from a 5-day cultures using a $5 \mathrm{~mm}$ sterile cork-borer and inversely placed on the surface of agar plate lawn with the $D$. zeae and were incubated at room temperature $\left(28{ }^{\circ} \mathrm{C}\right)$ for five days. The observation of antagonistic activity, which was indicated by the presence of inhibiting zones or clear zones around the actinomycete cultures in each plate, was conducted every day. Antagonistic activity was evaluated by measuring the diameter of inhibition zone (Zamanian 2005). Isolates with prominent clear zone showing high inhibitory activity were selected as the potential antagonistic actinomycetes and subjected to further characterizations.

\section{Characterization of antagonistic Actinomycetes}

Collected antagonistic isolates were characterized based on their cultural and morphological features of colonies grown on yeast malt-extract medium i.e. structure and color of the colonies, structure and color of substrate mycelia as well as aerial mycelia, and production of diffusible pigment (Jeffrey 2008). Aerial and substrate hyphae, spore chains, and ornamentation of spore surfaces scanning electron micrograph were taken using Zeiss EVO-MA 10. This scanning electron microscopy was performed at the Integrated Laboratory and Center of Technology Innovation (UPT Laboratorium Terpadu dan Sentra Inovasi Teknologi) the University of Lampung, Indonesia.

\section{S rDNA sequence-based characterization}

Molecular identification was conducted at the Laboratory of Industrial Microbiology - Research Centre for Biotechnology - Indonesian Institute of Sciences (Lembaga Ilmu Pengetahuan Indonesia, LIPI). Actinomycete isolates were grown in Erlenmeyer flasks containing $5 \mathrm{ml}$ of liquid modified ISP2 medium with agitation at $30{ }^{\circ} \mathrm{C}$ for overnight, then $3 \mathrm{ml}$ cultures were centrifuged at 13,000 rpm for $5 \mathrm{~min}$. The pellet was used for DNA genome extraction following the method of Ratnakomala et al. (2016). Primer 9F (5'-GAG TTT GAT CCT GGC TCA G-3') and primer1541R (5'-AAG GAG GTG ATC CAG CC-3') (Muraoka et al. 2008) were used for $16 \mathrm{~S}$ rDNA amplification using a thermal cycler (Eppendorf). This primer set produced amplicon at 1500 bp. PCR amplification was performed using Kappa ready mix master kit (KAPA Biosystem) in $50 \mu \mathrm{L}$ total volumes

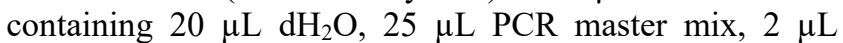
primer 9F ( $20 \mathrm{pmol}), 2 \mu \mathrm{L}$ primer $1541 \mathrm{R}(20 \mathrm{pmol})$, and 1 $\mu \mathrm{L}$ DNA template $(50 \mathrm{ng} / \mu \mathrm{L})$. The PCR programme used was an initial denaturation at $96{ }^{\circ} \mathrm{C}$ for 5 min, 30 cycles of denaturation at $96^{\circ} \mathrm{C}$ for $30 \mathrm{sec}$, annealing at $55^{\circ} \mathrm{C}$ for 50 sec, extension at $72^{\circ} \mathrm{C}$ for $1 \mathrm{~min}$, and a final extension at $72^{\circ} \mathrm{C}$ for $7 \mathrm{~min}$. The PCR products were electrophoresed on $1 \%$ agarose containing $1 \mathrm{x}$ TAE buffer (40mM Tris-Acetate and $1 \mathrm{mM}$ EDTA at 1 concentration) stained with DNA staining $(10 \mu \mathrm{L}$ flurosafe in $100 \mathrm{ml} 1 \mathrm{x}$ TAE buffer) and were visualized with the UV Trans-illuminator (Major science). For DNA sequencing, the PCR products of $16 \mathrm{Sr}$ DNA were sent to the Genetika Science Co. Jakarta. and sequencing results were analysed by BioEdit (ver. 7.2.6) (http://www.softpedia.com/get/Science-

CAD/BioEdit.shtml). Partial sequences of $16 \mathrm{~S}$ rDNA were compared and analysed for homology to the type strains in the database using NCBI BLAST (https://blast.ncbi.nlm.nih.gov) and EzTaxon Biocloud (Yoon et al. 2017). The phylogenetic tree was constructed using a neighbour-joining method by MEGA6 software (Tamura et al. 2013) and was bootstrapped using 1,000 replicates for each sequence (Kumar et al. 2011). 


\section{RESULTS AND DISCUSSION}

\section{Isolates of Actinomycetes}

The initial growth of actinomycete colonies isolated from pineapple rhizosphere was relatively slow, took about 3 days after incubation. After 2 weeks of incubation as many as 45 separated typical colonies were collected and plated in ISP2 media. Some of the colonies collected were varied in their sizes, colours, edges, and elevation (Figure 1). Colour series of colony surface included white, beige, grey, brown, yellow, and pink. The colonies of actinomycete isolates were commonly round-shaped with starchy surfaces and show powdery consistency, clear edges and tightly attached to the surface of the media (Figure 2). Microscopic observation showed that actinomycetes produced filamentous hyphae capable of forming dense mats called substrate mycelium. The aerial mycelia grew upward and some of aerial hyphae formed spore-like fungi. The spore-chains of actinomycetes were produced apically by aerial hyphae.

Actinomycetes have important ecological role because they were widely distributed in various habitats, sometimes also readily found in extreme environment and involved in important processes (Ghorbani-Nasrabani et al. 2013). The growth of actinomycetes was influenced by soil types and soil acidity, and the population of actinomycetes will be especially high in dry and alkaline soils (Athalye et al. 1981, Goodfellow and Williams, 1983). However, from this study it turned out that on pineapple rhizosphere on which the soil tends to be wet and acid $(\mathrm{pH}<6.0)$, various actinomycetes strains still can be collected. This became a good reason to explore new strains of actinomycetes from the local areas of pineapple plantation that might be potentially developed as biocontrol agents.

All of the collected isolates were confirmed as Grampositive bacteria based on Ryu nonstaining $\mathrm{KOH}$ technique (Powers 1995). In general, the actinomycetes isolated from the pineapple rhizosphere had variations in the colony shapes and colours, as well as the presence or absence of diffusible pigment produced in the growth medium. Some colonies revealed very similar aerial surface color but their based substrates were very different. Those variations could be an indication of the presence of different strains.
Sowndhararajan and Kang (2012) described that the colour of the aerial and substrate mycelia produced by actinomycetes varied with different media. Therefore, the use of only morphological and cultural characteristics may not be useful enough to identify the taxon status of each isolate.

\section{Antagonistic assay}

The results of antagonistic actinomycete screening of 45 isolates by agar diffusion method showed that 34 isolates formed clear zone around actinomycete colonies (Table 1). The clear zone indicated that the growth of $D$. zeae was inhibited by the actinomycetes. Oskay et al. (2004) stated that actinomycetes can produce secondary metabolites that acted as antibacterial. Antibacterial activity of actinomycetes against bacterial phytopathogens have been widely reported (Zamanian et al. 2005, El Karkouri et al. 2010, Wulandari and Sulistyani 2016). Actinomycetes, especially Streptomyces, also inhibited the growth of several soft rot bacteria such as E. carotovora subsp. carotovora (Pectobacterium carotovorum subsp. carotovorum), and E. chrysanthemi (P. chrysanthemi). Therefore, the presence of growing clear zone around the tested actinomycetes was presumably because of the antibacterial activity against $D$. zeae

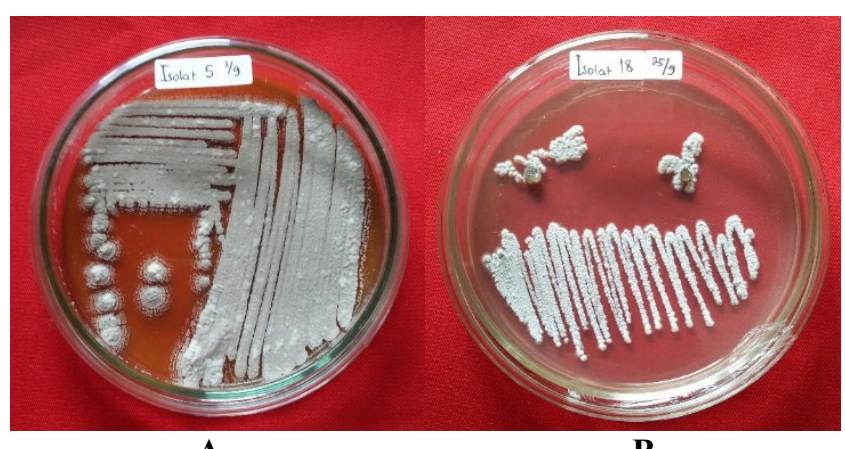

A

B

Figure 2. Two selected actinomycete isolates grown in ISP2 media at room temperature: (A) GGF2-i5 two weeks after inoculation, and (B) GGF4-i18 a week after inoculation.
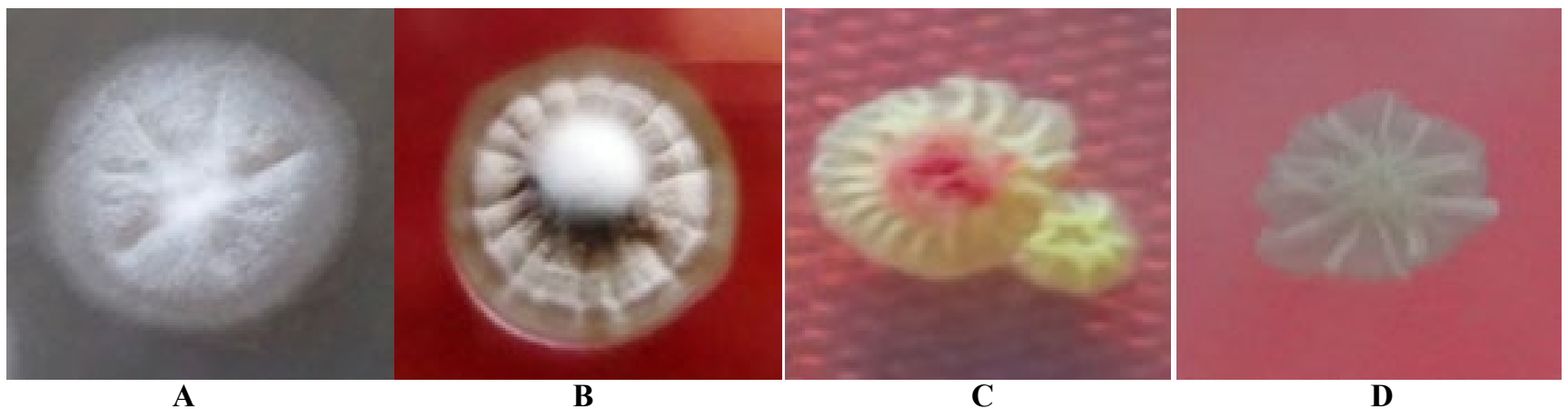

Figure 1. Some variations of shapes and colors of actinomycetes colonies isolated from pineapple rhizosphere in Lampung ProvinceIndonesia: isolate $A_{1}$ with diam. size $4.2 \mathrm{~mm}(\mathrm{~A})$; isolate GGF14-i26 diam. $3.4 \mathrm{~mm}(\mathrm{~B})$; isolate $\mathrm{A}_{2}$ diam. $2.2 \mathrm{~mm}(\mathrm{C})$; isolate $\mathrm{MJ}_{2}$ diam. $3.4 \mathrm{~mm}(\mathrm{D})$ 
Of 34 actinomycete isolates that exhibited inhibition activity against Dickey sp., fourteen of them had a bigger clear-zone than the positive control (chloramphenicol) (Table 1). This result indicated that those 14 strains may have a potency as bacterial antagonist and can be further studied to analyse their antibacterial compounds against $D$. zeae. It is suggested that pineapple plantation could be an important source to explore for active actinomycete strains potentially used as a biocontrol agent of D. zeae. Several studies concerning the role of actinomycetes as biocontrol agents for several soil-borne pathogens have been reported (Zamanian et al. 2005; El Karkouri 2010; Abdallah et al. 2013), and they were usually applied in the field as root protection.

Based on the diameter size of clear halo zone, there were two isolates that were promoted as the selected antagonist strains, namely GGF2-i5 and GGF4-i18 (Figure 3 ). Both of them were subjected to further characterization by $16 \mathrm{~S}$ rDNA sequence analysis to identify their taxon position. The difference sizes of clear halo zones can be an indication of the diversity of actinomycetes pineapple strains.

Table 1. Inhibition zone of in vitro growth of Dickeya zeae by actinomycetes five days after inoculation

\begin{tabular}{|c|c|}
\hline Isolate code & Diameter of clear zone $(\mathrm{mm})$ \\
\hline $\mathrm{A}_{1}$ & 8.62 \\
\hline $\mathrm{A}_{2}$ & 9.87 \\
\hline $\mathrm{A}_{3}$ & 1.00 \\
\hline $\mathrm{A}_{4}$ & 8.94 \\
\hline $\mathrm{A}_{7}$ & 5.47 \\
\hline $\mathrm{A}_{10}$ & 5.53 \\
\hline $\mathrm{A}_{11}$ & 4.36 \\
\hline $\mathrm{A}_{12}$ & 13.69 \\
\hline $\mathrm{MJ}_{1}$ & 8.94 \\
\hline $\mathrm{MJ}_{2}$ & 10.31 \\
\hline $\mathrm{MJ}_{3}$ & 4.97 \\
\hline $\mathrm{MJ}_{5}$ & 10.78 \\
\hline $\mathrm{MJ}_{6}$ & 11.06 \\
\hline $\mathrm{MJ}_{7}$ & 3.91 \\
\hline $\mathrm{MJ}_{8}$ & 9.50 \\
\hline $\mathrm{MJ}_{9}$ & 4.63 \\
\hline $\mathrm{MJ}_{10}$ & 3.59 \\
\hline $\mathrm{MJ}_{12}$ & 11.31 \\
\hline $\mathrm{MJ}_{14}$ & 2.28 \\
\hline GGF1-i1 & 0.47 \\
\hline GGF2-i5 & $16.00 *)$ \\
\hline GGF9-i10 & 1.91 \\
\hline GGF7-i16 & 1.58 \\
\hline GGF4-i18 & $19.44 *)$ \\
\hline GGF10-i20 & 2.88 \\
\hline GGF11-i21 & 3.32 \\
\hline GGF14-i26 & 7.54 \\
\hline GGF15-i27 & 3.63 \\
\hline GGF18-i30 & 3.32 \\
\hline NTF-2 & 6.63 \\
\hline NTF-3 & 4.00 \\
\hline NTF-4 & 2.10 \\
\hline NTF-5 & 4.38 \\
\hline NTF-30 & 1.10 \\
\hline Control (chloramphenicol) & 6.41 \\
\hline
\end{tabular}

\section{Characteristics of Actinomycetes}

The cultural characterization of 14 actinomycete strains showed that they varied in colony appearance such as the colour of the colony surface and pigment that diffuse and change the medium colour. The colonies colours ranged from bright white to dark blue with an elevated starchy surface (Figure 4). The observation by scanning electron microscope showed various different branched hypha and aerial hypha containing spore chains (Kumar et al. 2011). Strains of actinomycetes collected from pineapple rhizosphere samples revealed some characters including the various colour of aerial and substrate mycelia, structure of the substrate and aerial mycelia, branching of the hyphae containing spores, the structure of spore chains and spore surface and ornamentals. Photograph of actinomycetes strains GGF2-i5 and GGF4-i18 under scanning electron microscope is presented on Figure 5. The form of the spores varied from circular to ellipsoidal, and the spore surface was multifarious from velvety smooth to starchy rough. Based on aerial hypha and those mentioned typical characteristics, the actinomycete isolates from pineapple plantations were indicated as the genus Streptomyces. Among the genera of Actinomycetes, the genus Streptomyces was known in nature as the largest number of species and varieties, which differ greatly in their morphology, physiology and biochemical activities (Taddei et al. 1998; Suneetha et al. 2011).

\section{Phylogenetic analysis of 16S rDNA sequences}

The results of BLAST (https://blast.ncbi.nlm.nih.gov.) using $16 \mathrm{~S}$ rDNA sequence-based search showed that the two selected actinomycetes strains were assigned as the genus of Streptomyces. The phylogenetic analysis revealed that the GGF2-i5 and GGF4-i18 strains were in the same group with the reference strains of Streptomyces parvulus (NBRC 13193, acc. no. AB 184326) and Streptomyces hygroscopicus subsp. hygroscopicus (NBRC 13472, acc. no. BBOX01000593), respectively (Figure 6). Streptomyces is well-known as one genus of actinomycetes that produce many kinds of bioactive metabolite compounds. Streptomyces parvulus isolated from soil was reported as producer of peptide antibiotic actinomycin D (Inbar and Lapidot 1988) especially by $S$. parvulus CBJ1 (Cibi et al. 2016) and antimicrobial metabolites by Streptomyces parvulus DOSMB-D105 (Baskaran et al. 2016). Shaik et al. (2017) also reported that species of $S$. parvulus, known as an important producers of polypeptide antibiotic actinomycins, was tolerant to various physiological conditions in the marine environment. In this study, $S$. parvulus can be isolated from the soil of pineapple rhizosphere and exhibited antagonistic effect to D. zeae. This result proved that $S$. parvulus pineapple strain has the capability to produce bioactive metabolites under condition different from marine environment. The other antagonistic strain of actinomycetes isolated from pineapple rhizosphere is $S$. hygroscopicus subsp. hygroscopicus. This subspecies of $S$. hygroscopicus was reported as one of important sources to find new bioactive metabolites since more than 650 kinds of bioactive compounds were found from the members of S. hygroscopicus (Komaki et al. 2016). The two 
Streptomyces species isolated from pineapple rhizosphere need further study to find their excellence as biocontrol agents of D. zeae, the causal agent of pineapple soft rot. Both of the 16S rRNA gene sequences from those two species were deposited in the GenBank with the accession number MH170279 and MH170280, respectively. The study of actinomycetes collected from pineapple rhizosphere is considered as the first report in Lampung Province, Indonesia.

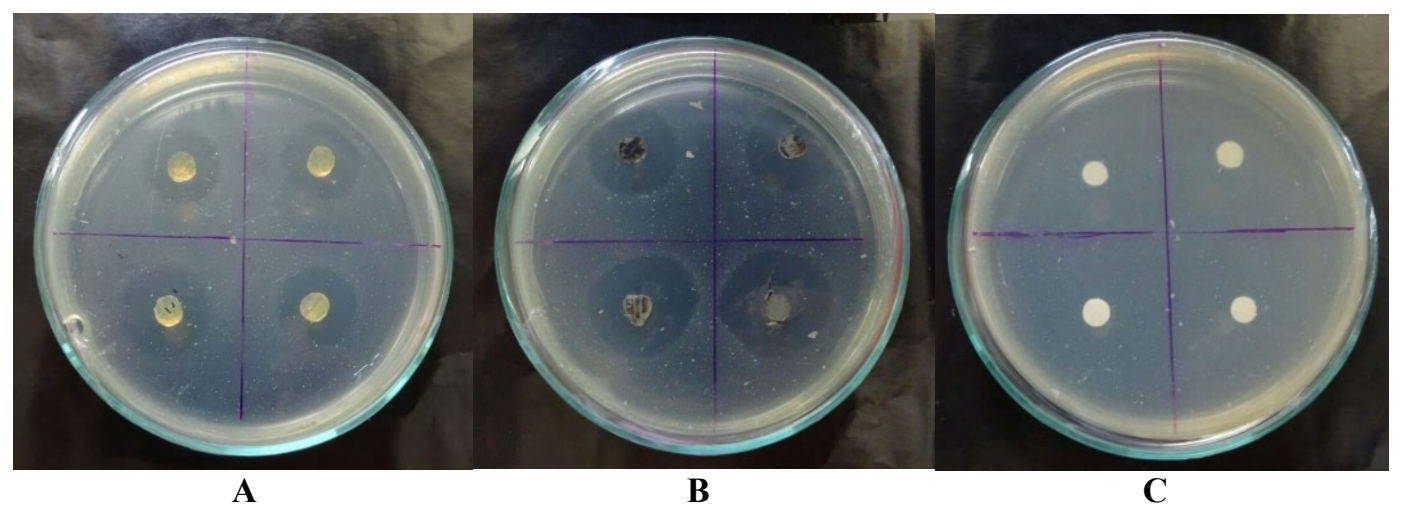

Figure 3. Formation of a clear zone around the actinomycete culture strains GGF2-i5 (A), GGF4-i18 (B), and chloramphenicol as the control (C) in D. zeae lawn in PPGA media 24 hours after inoculation, incubated at room temperature. Each plate consisted of four plugs of the same strain as the replication. The clear zone indicated that the two strains (GGF2-i5 and GGF4-i18) showed the biggest inhibition effect against $D$. zeae. The control (chloramphenicol) showed very slightly clear zone
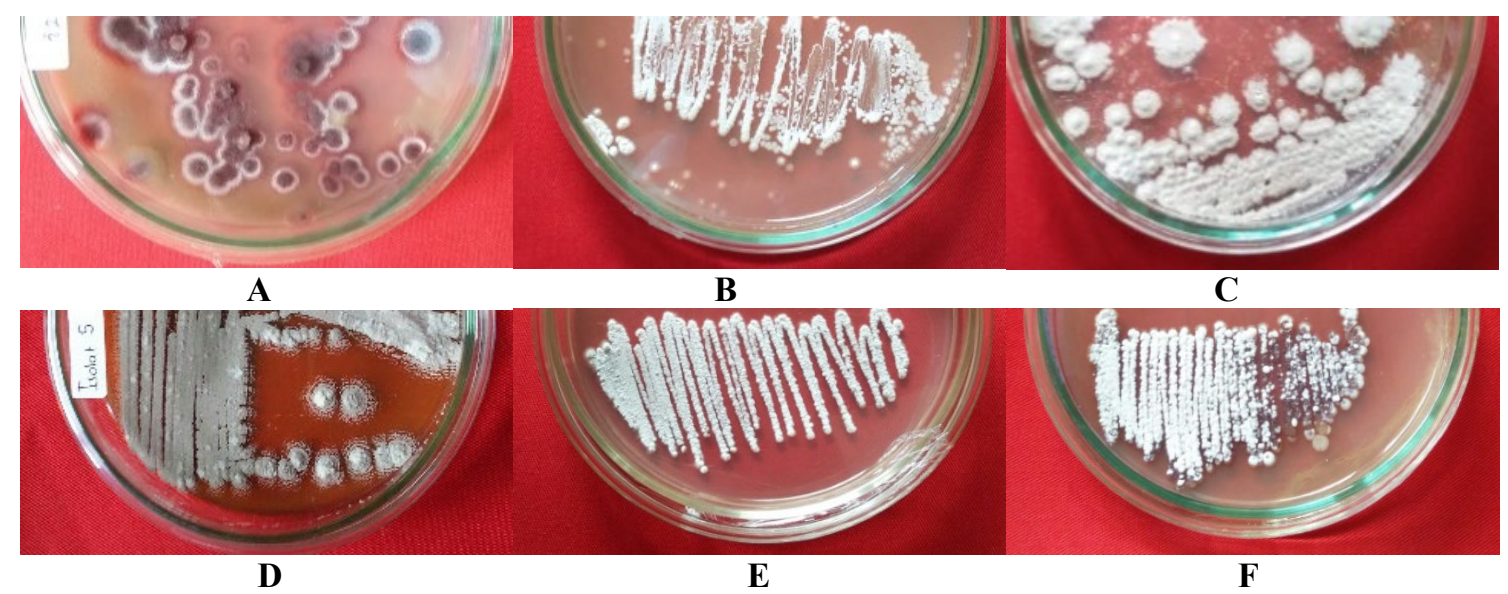

Figure 4. Variation of the colonies of representative antagonistic actinomycete strains on ISP2 media, grown at room temperature 14 days after inoculation. Note: A. A2, B. A12, C. MJ8, D. GGF2-i5, E. GGF4-i18, F. GGF14-i26

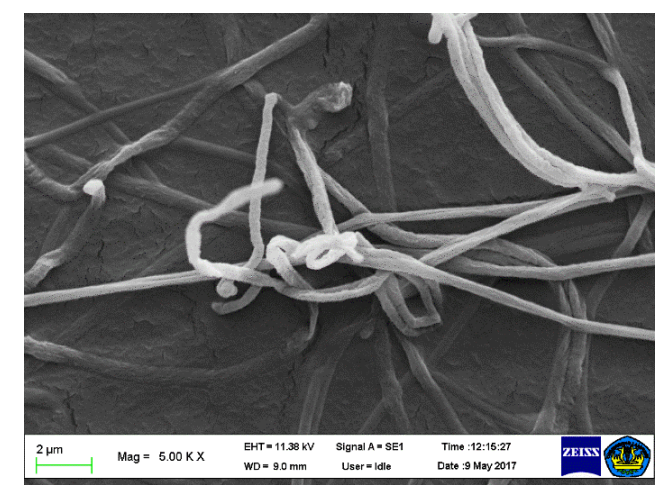

A

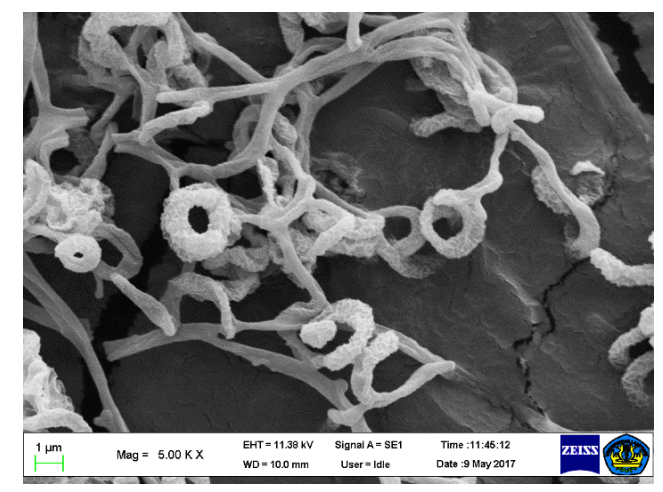

B

Figure 5. Photograph of actinomycete strains GGF2-i5 (A) and GGF4-i18 (B) under scanning electron microscope at 5000x magnification 


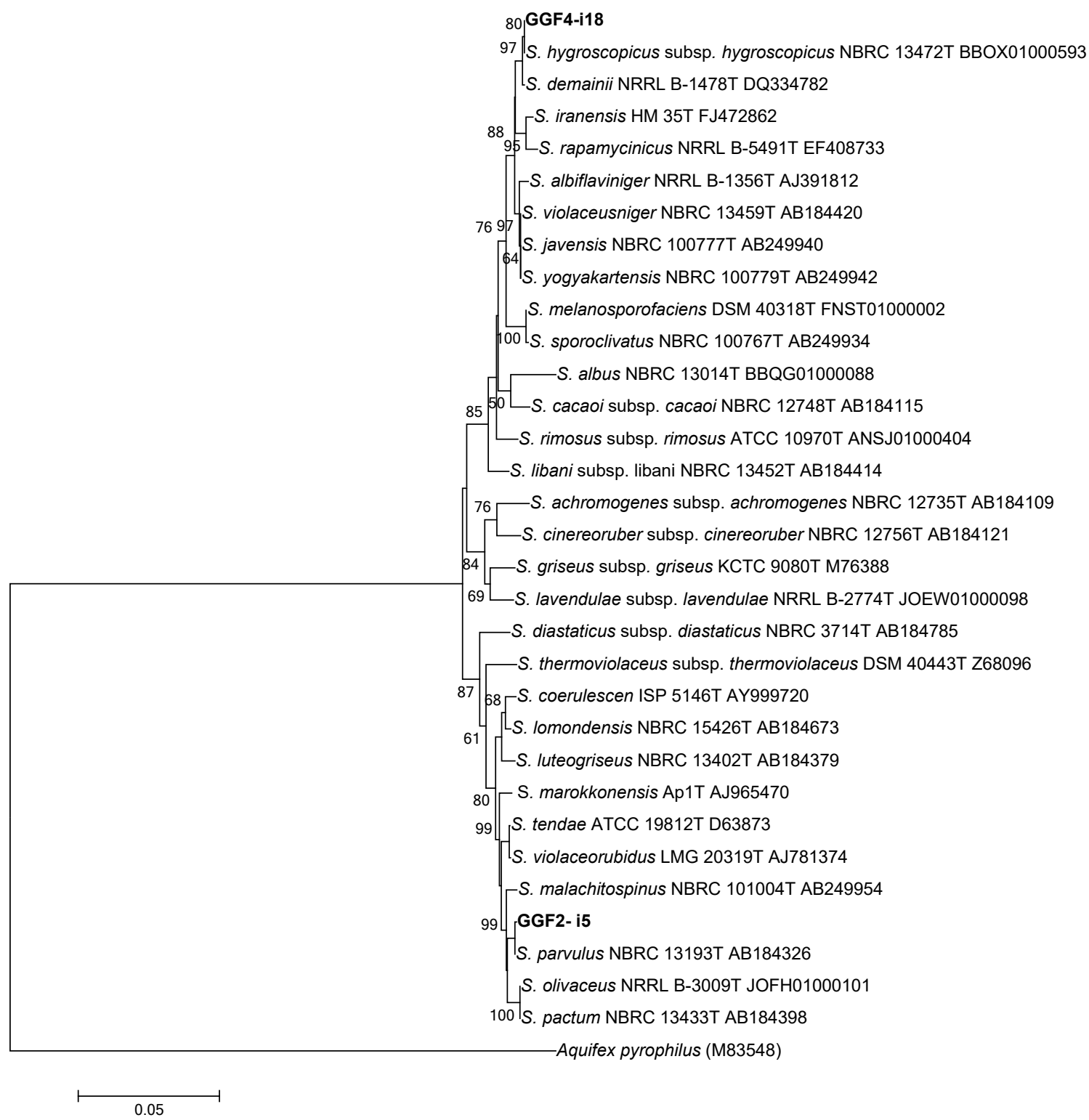

Figure 6. Phylogenetic tree of $16 \mathrm{~S}$ rDNA sequences for actinomycetes strain GGF2-i5 and GGF4-i18 were generated by the NeighborJoining method using MEGA6 (Tamura et al. 2013) with bootstrap 1000x

\section{ACKNOWLEDGEMENTS}

This study was supported by the Ministry of Research, Technology and Higher Education, Republic of Indonesia, through a fundamental research program of the University of Lampung, Indonesia in the 2017 fiscal year. Thanks is also extended to the Nusantara Tropical Farm Co. (Great Giant Food Co.), Winarno and Yayan for allowing us to collect the samples from their pineapple plantations, Meri D. Saputri, Wulandari, Widyaningrum A.Sari and Dinihari I. Kusumawati for their technical assistance.

\section{REFERENCES}

Abdallah ME, Haroun SA, Gomah AA, El-Naggar NE, Badr HH. 2013. Application of actinomycetes as biocontrol agents in the management of onion bacterial rot diseases. Arch Phytopathol Plant Protect 46 (15): 1797-1808.

Al-Momani F, Saadoun I, Malkawi HI. 1999. Streptomyces species from Jordan soils with in vitro inhibitory activity against Agrobacterium tumefaciens Ab 136 pti 854. Afr Plant Protect 5 (2): 129-130.

Athalye M, Lacey J, Goodfellow M. 1981. Selective isolation and enumeration of actinomycetes using rifampicin. J Appl Bacteriol 51(2): 289-297. 
Barakate M, Ouhdouch Y, Oufdou K, Beaulieu C. 2002. Characterization of rhizospheric soil Streptomycetes from Moroccan habitats and their antimicrobial activities. World J Microbiol Biotechnol 18 (1): 49-54.

Baskaran R, Mohan PM, Sivakumar K, Kumar A. 2016. Antimicrobial activity and phylogenetic analysis of Streptomyces parvulus DosmbD105 isolated from the mangrove sediments of Andaman Islands. Acta Microbiol Immunol Hung 63 (1): 27-46.

Cibi R, Nair AJ. 2016. Purification of actinomycin D from Streptomyces parvulus isolated from mangrove ecosystem of Kerala, India. Int J Curr Microbiol Appl Sci 5 (7): 461-467.

Dhananjeyan V, Selvan N, Dhanapal K. 2010. Isolation, characterization, screening and antibiotic sensitivity of actinomycetes from locally (near MCAS) collected soil samples. J Biol Sci 10 (6): 514-519.

Dharmaraj S, Dhevendaran K. 2010. Evaluation of Streptomyces as a probiotic feed for the growth of ornamental fish Xiphophorus helleri. Food Technol Biotechnol 48 (4): 497-504.

El Karkouri A, El Hassani FZ, El Mzibri M, Benlemlih M, El Hassouni M. 2010. Isolation and identification of an actinomycete strain with a biocontrol effect on the phytopathogenic Erwinia chrysanthemi 3937VIII responsible for soft rot disease. Ann Microbiol 60 (2): 263 268.

Ghorbani-Nasrabadi R, Greiner R, Alikhani HA, Hamedi J, Yakhchali B. 2013. Distribution of actinomycetes in different soil ecosystems and effect of media composition on extracellular phosphatase activity. J Soil Sci Plant Nutr 1313 (11): 223-236.

Goodfellow M, Kumar Y, Labeda DP, Sembiring L. 2007. The Streptomyces violaceusfsdfdsniger clade: a home for Streptomycetes with rugose ornamented spores. Antonie van Leeuwenhoek 92 (2) 173-199.

Goodfellow M, Williams ST. 1983. Ecology of actinomycetes. Ann Rev Microbiol 37 (41): 189-216.

Ibrahim SY, El-Salam MMA. 2016. Isolation of anti-fungal agent from a soil inhabitant Streptomyces albaduncus-M51 and its efficacy against osmophilic food spoilage by Saccharomyces cerevisiae. J Environ Occup Sci 5 (2): 38-46.

Inbar L, Lapidot A. 1988. Metabolic regulation in Streptomyces parvulu. during actinomycin D synthesis, studied with $13 \mathrm{C}$ - and $15 \mathrm{~N}$-labeled precursors by $13 \mathrm{C}$ and $15 \mathrm{~N}$ nuclear magnetic resonance spectroscopy and by gas chromatography-mass spectrometry. J Bacteriol 170 (9): 4055-4064.

Jeffrey LSH. 2008. Isolation, characterization and identification of actinomycetes from agriculture soils at Semongok, Sarawak. Afr J Biotechnol 7 (20): 3697-3702.

Kaur T, Sharma D, Kaur A, Manhas RK. 2013. Antagonistic and plant growth promoting activities of endophytic and soil actinomycetes. Arch Phytopathol Plant Protect 46 (14): 1756-1768.

Katili AS, Retnowati Y. 2017. Isolation of Actinomycetes from mangrove ecosystem in Torosiaje, Gorontalo, Indonesia. Biodiversitas 18 (2) 826-833.

Komaki H, Ichikawa N, Oguchi A, Hamada M, Tamura T, Suzuki K, Fujita N. 2016. Draft genome sequence of Streptomyces hygroscopicus subsp. hygroscopicus NBRC 16556. Genome Announc 4 (3): e00139-16. DOI: 10.1128/genomeA.00139-16.

Kumar V, Bharti A, Gusain O, Bisht GS. 2011. Scanning electron microscopy of Streptomyces without use of any chemical fixatives. Scanning 33 (6): 446-449.
Muraoka W, Nakashima T, Tabeira Y, Eguchi H, Imagawa K, Matsumura Y, Takeshita S, Takemasa T. 2008. Characterization of Burkholderia sp. Y1 isolated from oil polluted soil. J Environ Biotech 8 (1): 43-47.

Nithya B, Ponmurugan P. 2012. Studies on actinomycetes diversity in Eastern Ghats (Yercaud Hills) of Southern India for secondary metabolite production. Int J Agric Res 7 (3): 152-159.

Oskay M, Tamer AÜ, Azeri C. 2004. Antibacterial activity of some actinomycetes isolated from farming soils of Turkey. Afr J Biotechnol 3 (9): 441-446.

Patil R, Jeyasekaran G, Shanmugaran SA. 2016. Bio-activity of marine actinomycetes against food-borne human pathogens. Intl J Sci Nat 7 (3): 582-586.

Powers EM. 1995. Efficacy of the Ryu nonstaining $\mathrm{KOH}$ technique for rapidly determining gram reactions of food-borne and waterborne bacteria and yeasts. Appl Environ Microbiol 61 (10): 3756-3758.

Prasetyo J, Aeny TN. 2014. Pineapple Fruit Collapse: Newly emerging disease of pineapple fruit in Lampung, Indonesia. J HPT Tropika 14 (1): 96-99.

Putra C, Giyanto G. 2014. Kompatibilitas Bacillus spp. dan aktinomiset sebagai agens hayati Xanthomonas oryzae pv. oryzae dan pemacu pertumbuhan padi. J Fitopatol Indonesia 10 (1): 160-169. [Indonesian].

Ratnakomala S, Lisdiyanti P, Prayitno NR, Triana E, Lestari Y, Hastuti RD, Otoguro M, Widyastuti Y, Ando K, Sukara E, Karya E. 2016. Diversity of actinomycetes from Eka Karya Botanical Garden Bali. Biotropia 23 (1): 42-51.

Saadoun I, Al-Momani F, Elbetieha A. 1999. Genetic determinants of active antibiotic-producing soil Streptomycetes. New Microbiol 22 (3): 233-239.

Shaik M, Sankar GG, Iswarya M, Rajita P. 2017. Isolation and characterization of bioactive metabolites producing marine Streptomyces parvulus srain Sankarensis-A10. J Genet Eng Biotech 15 (1): 87-94.

Sowndhararajan K, Kang SC. 2012. In vitro antagonistic potential of Streptomyces sp. AM-S1 against plant and human pathogens. J Agr Chem Environ 1 (1): 41-47.

Suneetha V, Raj K, Prathusha K. 2011. Isolation and identification of Streptomyces ST1 and ST2 strains from Tsunami affected soils: Morphological and biochemical studies. J Oceanogr Mar Sci 2 (4): 96-101.

Taddei A, Tremarias MM, De Capriles CH. 1998. Viability studies on actinomycetes. Mycopathologia 143 (3): 161-164.

Tamura K, Stecher G, Peterson D, Filipski A, Kumar S. 2013. MEGA6: Molecular evolutionary genetics analysis Version 6.0. Mol Biol Evol 30 (12): 2725-2729.

Wulandari S, Sulistyani N. 2016. Pengaruh media terhadap pertumbuhan isolat aktinomisetes kode AL35 serta optimasi produksi metabolit antibakteri berdasarkan waktu fermentasi dan pH. Media Farmasi 13 (2): 186-198. [Indonesian].

Yoon SH, Ha SM, Kwon S, Lim J, Kim Y, Seo H, Chun J. 2017. Introducing EzBioCloud: A taxonomically united database of $16 \mathrm{~S}$ rRNA gene sequences and whole-genome assemblies. Int J Sys Evol Microbiol 67 (5): 1613-1617.

Zamanian S, Bonjar GHS, Saadoun I.. 2005. First report of antibacterial properties of a new strain of Streptomyces plicatus (Strain 101) against Erwinia carotovora subsp. carotovora from Iran. Biotechnol (Faisalabad) 4 (2): 114-120. 